\title{
Development of a multiplex qPCR assay for the simultaneous detection of Mycoplasma bovis, Mycoplasma species, and Acholeplasma laidlawii in milk
}

\author{
Kanika Chauhan ${ }^{1,2,3}$, Sharif S Aly ${ }^{1,2}$, Terry W Lehenbauer ${ }^{1,2}$, Karen H Tonooka ${ }^{1}$, Kathy Glenn ${ }^{1}$, Paul Rossitto ${ }^{1}$, \\ Maria L Marco ${ }^{\text {Corresp. } 3}$ \\ ${ }^{1}$ Veterinary Medicine Teaching \& Research Center, School of Veterinary Medicine, University of California, Davis, Tulare, CA, United States \\ 2 Department of Population Health and Reproduction, School of Veterinary Medicine, University of California, Davis, Davis, CA, United States \\ 3 Department of Food Science and Technology, University of California, Davis, Davis, CA, United States \\ Corresponding Author: Maria L Marco \\ Email address: mmarco@ucdavis.edu
}

Contagious bovine mastitis caused by Mycoplasma bovis and other Mycoplasma species including Mycoplasma californicum, Mycoplasma bovigenitalium, Mycoplasma alkalescens, Mycoplasma arginini, and Mycoplasma canadense is an economical obstacle affecting many dairy herds throughout California and elsewhere. Routine bacteriological culturebased assays for the pathogens are slow and subject to false-positive results due to the presence of the related, non-pathogenic species Acholeplasma laidlawii. To address the need for rapid and accurate detection methods, a new TaqMan multiplex, quantitative realtime PCR (qPCR) assay was developed that targets the 16S rRNA gene of Mycoplasma, rpoB gene of $M$. bovis, and the $16 \mathrm{~S}$ to $23 \mathrm{~S}$ rRNA intergenic transcribed spacer (ITS) region of $A$. laidlawii. qPCR amplification efficiency and range of detection were similar for individual assays in multiplex as when performed separately. The multiplex assay was able to distinguish between $M$. bovis and $A$. laidlawii as well as detect Mycoplasma spp. collectively, including Mycoplasma californicum, Mycoplasma bovigenitalium, Mycoplasma canadense, Mycoplasma arginini and Mycoplasma alkalescens. In milk, the lower limit of detection of $M$. bovis, M. californicum, and A. laidlawii with the multiplex assay was between 120 to 250 colony forming units (CFU) per $\mathrm{mL}$. The assay was also able to simultaneously detect both M. bovis and A. laidlawii in milk when present in moderate $\left(10^{3}\right.$ to $10^{4} \mathrm{CFU} / \mathrm{mL}$ ) to high $\left(10^{6}\right.$ to $\left.10^{7} \mathrm{CFU} / \mathrm{mL}\right)$ quantities. Compared to laboratory culturebased methods, the multiplex qPCR diagnostic specificity (Sp) was 100\% (95\% Cl 86.8, $100 ; n=26)$ and diagnostic sensitivity (Se) was $92.3 \%(95 \% \mathrm{Cl}: 74.9,99.1 ; n=26)$ for Mycoplasma species in milk samples collected from California dairy farms. Similarly, the Sp was $100 \%(95 \% \mathrm{Cl} 90.5,100 ; n=37)$ and Se was 93.3\% (95\% Cl: 68.1, 99.8; $n=15)$ for $M$. bovis. Our assay can detect and distinguish among M. bovis, other prevalent Mycoplasma Peer) reviewing PDF | (2021:03:58967:1:0:NEW 20 Jun 2021) 
spp., and non-pathogenic Acholeplasma laidlawii for effective identification and control of Mycoplasma mastitis, ultimately supporting dairy cattle health and high-quality dairy products in California. 
1 Development of a multiplex qPCR assay for the simultaneous detection of Mycoplasma

2 bovis, Mycoplasma species, and Acholeplasma laidlawii in milk

3

4 Kanika Chauhan ${ }^{1,2,3}$, Sharif S. Aly ${ }^{2,3}$, Terry W. Lehenbauer ${ }^{2,3}$ Karen Tonooka $^{2}$, Kathy

5 Glenn², Paul Rossitto², Maria L. Marco $^{1 \dagger}$

6

$7 \quad{ }^{1}$ Department of Food Science and Technology, University of California, Davis, California, USA

$8{ }^{2}$ Veterinary Medicine Teaching \& Research Center, School of Veterinary Medicine, University

9 of California Davis, Tulare, CA

$10{ }^{3}$ Department of Population Health and Reproduction, School of Veterinary Medicine, University

11 of California, Davis

12

$13 \uparrow$ Corresponding author:

14 Maria L Marco

15 One Shields Avenue

16 University of California, Davis

17 Davis, CA 95616

18 Email:mmarco@ucdavis.edu

19

20

21 Short title: Multiplex assay for bovine Mycoplasma detection

22 


\section{ABSTRACT}

24 Contagious bovine mastitis caused by Mycoplasma bovis and other Mycoplasma species

25 including Mycoplasma californicum, Mycoplasma bovigenitalium, Mycoplasma alkalescens,

26 Mycoplasma arginini, and Mycoplasma canadense is an economical obstacle affecting many

27 dairy herds throughout California and elsewhere. Routine bacteriological culture-based assays

28 for the pathogens are slow and subject to false-positive results due to the presence of the related,

29 non-pathogenic species Acholeplasma laidlawii. To address the need for rapid and accurate

30 detection methods, a new TaqMan multiplex, quantitative real-time PCR (qPCR) assay was

31 developed that targets the 16S rRNA gene of Mycoplasma, rpoB gene of M. bovis, and the 16S to

32 23S rRNA intergenic transcribed spacer (ITS) region of A. laidlawii. qPCR amplification

33 efficiency and range of detection were similar for individual assays in multiplex as when

34 performed separately. The multiplex assay was able to distinguish between $M$. bovis and $A$.

35 laidlawii as well as detect Mycoplasma spp. collectively, including Mycoplasma californicum,

36 Mycoplasma bovigenitalium, Mycoplasma canadense, Mycoplasma arginini and Mycoplasma

37 alkalescens. In milk, the lower limit of detection of M. bovis, M. californicum, and A. laidlawii

38 with the multiplex assay was between 120 to 250 colony forming units (CFU) per mL. The assay

39 was also able to simultaneously detect both M. bovis and A. laidlawii in milk when present in

40 moderate $\left(10^{3}\right.$ to $\left.10^{4} \mathrm{CFU} / \mathrm{mL}\right)$ to high $\left(10^{6}\right.$ to $\left.10^{7} \mathrm{CFU} / \mathrm{mL}\right)$ quantities. Compared to laboratory

41 culture-based methods, the multiplex qPCR diagnostic specificity (Sp) was 100\% (95\% CI 86.8,

$42100 ; \mathrm{n}=26)$ and diagnostic sensitivity (Se) was 92.3\% (95\% CI: 74.9, 99.1; $\mathrm{n}=26)$ for

43 Mycoplasma species in milk samples collected from California dairy farms. Similarly, the Sp

44 was $100 \%(95 \%$ CI 90.5, 100; $\mathrm{n}=37)$ and Se was 93.3\% (95\% CI: 68.1, 99.8; $\mathrm{n}=15)$ for M. bovis.

45 Our assay can detect and distinguish among M. bovis, other prevalent Mycoplasma spp., and 
46 non-pathogenic Acholeplasma laidlawii for effective identification and control of Mycoplasma

47 mastitis, ultimately supporting dairy cattle health and high-quality dairy products in California.

48 Key Words: milk, bovine mastitis, qPCR, multiplex, Taqman, diagnostic, Mycoplasma

\section{INTRODUCTION}

Mastitis caused by Mycoplasma species is highly infectious in dairy cattle and causes

52 serious disease and economic burdens, especially in large dairy herds in the U.S. and other

53 countries worldwide (Nicholas et al., 2016). Pathogenic Mycoplasma spp. are unique compared

54 to most other bacterial causes of mastitis because they lack a cell wall and possess less genetic

55 code (Fox et al., 2005). These organisms infect the udder tissue of dairy cows, and the resultant

56 disease has long-term effects on milk quality, yield, and animal health (Nicholas et al., 2016). In

57 the US alone, the mean cost per clinical mastitis case caused by organisms other than Gram-

58 positive and Gram-negative bacteria, which included Mycoplasma spp., was estimated at US

$59 \$ 95.31$ annually, with majority of the costs attributed to treatment (Cha et al., 2011). However,

60 because of the very contagious nature and recognized poor response to therapy, dairy cattle with

61 udder infections due to Mycoplasma spp. are often removed from the herd following

62 identification of infection which significantly adds to the economic burden of mycoplasma

63 mastitis (Ball, 1999; Maunsell et al., 2011; Nicolas et al., 2016). The most prevalent species

64 causing cattle mastitis is Mycoplasma bovis, but other Mycoplasma species including

65 Mycoplasma californicum and Mycoplasma bovigenitalium are also of diagnostic interest to

66 dairy cattle farmers in California (Kirk et al., 1997; Infante-Martinez et al., 1999; Brenner et al.,

67 2009). 

treatment, and can result in chronic and subclinical states of infection. Because Mycoplasma can

70 spread quickly, this disease is particularly detrimental to large ( $>500$ cow) dairy herds (Jasper,

71 1982; Pfutzner and Sachse, 1996). For these reasons, screening of bulk tank milk or pooled

72 animal milk samples is important to facilitate removal of infected animals thereby limiting the

73 spread of infection. Routine Mycoplasma investigations involve using laboratory-culture based

74 methods to enrich the bacteria from milk. This approach is challenging considering the numerous

75 nutrient requirements and specific incubation conditions required for Mycoplasma growth. Even

76 under optimal conditions, some mycoplasma strains are still difficult to grow on standard

77 laboratory culture media (Razin, 1996). Other challenges include the extended incubation time

78 (approximately 7 to 10 days) required before reaching sufficient cell numbers for analysis and

79 also the analyzing needed to identify Mycoplasma at the species level usually by serological

80 testing. Additionally, phenotypic similarities between Mycoplasma spp. and commensal

81 environmental contaminants, most predominantly, Acholeplasma laidlawii, can result in false

82 positives (Pfutzner and Sachse, 1996; Clothier et al., 2010; Fox, 2012).

83 Nucleic-acid based, culture-independent methods are now compelling alternatives for

84 Mycoplasma diagnosis because of their potential to be rapid, accurate, and cost effective. Use of

85 PCR and qPCR-based tests, in particular, have the most promise to be the most rapid and reliable 86 methods for Mycoplasma spp. detection, identification, and quantification. To this regard, several 87 end-point PCR and quantitative real-time PCR (qPCR) assays for M. bovis have been developed targeting M. bovis 16S rRNA (van Kuppeveld et al., 1992; Chavez Gonzalez et al., 1995; 
90

91

Gioia et al., 2016; Behera et al., 2018), oppD (Sachse et al., 2010), fusA (Boonyayatra et al., 2012), and gltX (Appelt et al., 2019).

When assessing outbreaks of mycoplasma mastitis in dairies, especially for California's large dairy herds, multiplex qPCR can be a favorable and practical approach for diagnostic testing. The use of different primer and probe sets in a single reaction tube significantly shortens the detection times and increases throughput capacity (Chapela et al., 2015). A multiplex qPCR assay was developed to detect M. bovis, M. californicum, and M. bovigenitalium in milk samples with a limit of detection of between $10^{2}$ to $10^{5}$ colony forming units (CFU) per mL (Parker et al., 2017). There are also commercially-available, multiplex qPCR kits for milk such as PathoProof, Mastitis Major-3 kit (Thermo Fisher Scientific, Finland), and bactotype Mastits HP3 PCR Kit (Qiagen, Leipzig, Germany) designed to detect M. bovis along with the other contagious mastitis pathogens Staphylococcus aureus and Streptococcus agalactiae. However, compared to Mycoplasma spp., both $S$. aureus and $S$. agalactiae are relatively easy to isolate using conventional aerobic culture methods with final results available within 48 hours.

In this study, we developed a multiplex qPCR assay for detection of Mycoplasma spp., M. bovis, and A. laidlawii. The specificity and quantification range were verified for the individual primer sets as well as in multiplex. The multiplex assay was then tested for its diagnostic capability compared to routine laboratory, culture-based methods.

\section{MATERIAL AND METHODS}

\section{Bacterial strains and milk samples}

M. bovis ATCC 25523, M. californicum ATCC 33461, M. bovigenitalium ATCC 19852, Mycoplasma canadense ATCC 29410, Mycoplasma arginine ATCC 23838, Mycoplasma alkalescens ATCC 29103 and A. laidlawii ATCC 23206 were purchased from the American 
114 Type Culture Collection (ATCC, Manassas, VA) (Table 1). M. bovis ATCC 25523 and $A$.

115 laidlawii ATCC 23206 genomic DNA (gDNA) was also purchased from the ATCC.

116 Field isolates of Mycoplasma and Acholeplasma were obtained by routine bacteriological

117 testing of milk samples submitted by producers and milk processors to the Milk Quality

118 Laboratory (MQL) of the University of California, Davis Veterinary Medicine Teaching and

119 Research Center (VMTRC, Tulare, CA) from individual cows and bulk tanks located at dairies in 120 the Central Valley, California (Table 1). All Mycoplasma and Acholeplasma isolates were

121 recovered using VMTRC MQL protocols adapted from the National Mastitis Council (US,

122 2004). Briefly, milk samples were plated on modified mycoplasma agar (University of California

123 Davis Veterinary Medicine Biological Media Services) directly upon receipt and after

124 enrichment in mycoplasma specific broth (UC Davis VM Biological Media Services) for $48 \mathrm{~h}$ in $1254 \% \mathrm{CO}_{2}$ at $37^{\circ} \mathrm{C}$. Putative Mycoplasma and Acholeplasma colonies were streaked for isolation

126 and subsequently identified to the species level by staining with fluorescent antibodies according 127 to previously described methods (Baas and Jasper, 1972). To discriminate between A. laidlawii 128 and Mycoplasma spp., a digitonin disk inhibition test was performed according to the method 129 previously described (Thurmond et al., 1989). All isolates were stored in 15\% (v/v) glycerol at $13080^{\circ} \mathrm{C}$.

131 Additionally, a total of 33 isolates from 30 different bacterial species other than

132 mycoplasmas and commonly found in bovine milk were used for cross-specificity evaluation of 133 the qPCR assay (Table 1). These isolates were either obtained from the ATCC as type strains or 134 isolated at the MQL and Dairy Food Safety Laboratory (DFSL) of University of California, 135 Davis Veterinary Medicine Teaching and Research Center (VMTRC, Tulare, CA) from routine 136 diagnostic milk sample submissions from dairies by producers located in the Central Valley, CA. 
137 Species identity was confirmed by $16 \mathrm{~S}$ rRNA gene and rpoB sequencing (Drancourt et al., 2000; 138 Drancourt and Raoult 2002).

139

140

141

142

143

144

145

146

147

148

149

150

151

152

153

154 155

156

157

158 159

\section{Genomic DNA extraction}

The DNeasy Blood and Tissue Lysis kit (Qiagen, Carlsbad, CA) was used for bacterial gDNA extraction and purification according to the manufacturer's instructions. The gDNA was extracted from Mycoplasma and Acholeplasma strains after incubation in mycoplasma specific broth (UC Davis VM Biological Media Services) at $37{ }^{\circ} \mathrm{C}$ in $4 \% \mathrm{CO}_{2}$ for between 24 to $72 \mathrm{~h}$ (Appelt et al., 2019). The gDNA from other bacterial species (Table 1) was isolated from colonies retrieved from bovine blood agar plates (UC Davis VM Biological Media Services) after incubation at $37^{\circ} \mathrm{C}$ for 24 to $48 \mathrm{~h}$. The commercial kit was used for the isolation of gDNA because raw milk may contain PCR inhibitors that affect the sensitivity of the assay or even lead to false negative results (Schrader et al., 2012). For gDNA extractions from bacteria contained in milk, $1 \mathrm{~mL}$ milk was centrifuged at $18,407 \mathrm{x} g$ for $10 \mathrm{~min}$. The resulting pellet was then suspended in Buffer ATL (Qiagen, Carlsbad, CA) and Proteinase K (Qiagen, Carlsbad, CA) for incubation at $56^{\circ} \mathrm{C}$ for $1 \mathrm{~h}$ with continuous mixing prior to DNA extraction and purification. The gDNA concentrations were measured on a Qubit 3.0 Fluorometer using the Qubit dsDNA HS Assay Kit (Life Technologies, Eugene, OR). All gDNA was stored at $-20{ }^{\circ} \mathrm{C}$ until analysis or at $4{ }^{\circ} \mathrm{C}$ for no longer than 2 to 4 weeks.

qPCR primer design

Clustal W (Thompson et al., 1994) was used to identify conserved and variable Mycoplasma and Acholeplasma DNA targets for the development of new primer-probe pairs to

Peer] reviewing PDF | (2021:03:58967:1:0:NEW 20 Jun 2021) 
160 be used in the multiplex qPCR assay. DNA sequence alignments were performed for 16S rRNA,

$161 r p o B$ and intergenic transcribed spacer (ITS) region between 16S and 23S rRNA genes in $M$.

162 bovis, . californicum, M. bovigenitalium, M. canadense M. alkalescens, and A. laidlawii. Those

163 Mycoplasma species were selected for primer development because of their prevalence in

164 Mycoplasma mastitis reported in the US dairy herds (Fox, 2012; Nicholas et al., 2016) and by

165 the VMTRC MQL. The following strains were used for primer selection: M. bovis strain PG45

166 (ATCC 25523, NC_014760) (Wise et al., 2011), M. californium strain ST-6 (ATCC 33461,

167 NZ_CP007521) (Calcutt et al., 2014), M. bovigenitalium strain HAZ (ATCC 19852, AP017902)

168 (Edward and Freundt, 1956), M. canadense strain HAZ 360_1 (ATCC 29410, NZ_AP014631),

169 M. alkalescens 14918 (ATCC 29103, NZ_AMWK01000000), and A. laidlawii PG-8A (ATCC

170 23206, NC_010163) (Lazarev et al., 2011). DNA sequence alignments showed sufficient

171 nucleotide variation in the 16S rRNA and rpoB genes and ITS region for primer and Taqman

172 probe design (Supplementary Figure 1).

173

All qPCR primers and Taqman probes were designed using Primer-BLAST and Primer

174 Express software (Applied Biosystems) (Table 2 and Supplementary Figure 1). Primers were

175 regarded to be acceptable if they contained at least two total mismatches to unintended targets,

176 including at least two mismatches within the last five base pairs of the 3 ' end. All primers were

177 designed to have a melting temperature at $59{ }^{\circ} \mathrm{C}$ to $62{ }^{\circ} \mathrm{C}$ and an amplicon size between 108 to $178232 \mathrm{bp}$.

179

180

\section{qPCR assay parameters}

All primers and probes were optimized by testing concentrations in the range of $100 \mathrm{nM}$

182 to $400 \mathrm{nM}$ and $75 \mathrm{nM}$ to $400 \mathrm{nM}$, respectively. qPCR amplification was performed in 96-well 
183 plates on an Applied Biosystems 7500 Fast thermal cycler (Applied Biosystems, Carlsbad, CA)

184 with an initial denaturation step of $5 \mathrm{~min}$ at $95{ }^{\circ} \mathrm{C}$ followed by 40 cycles of $45 \mathrm{~s}$ at $95{ }^{\circ} \mathrm{C}$ for

185 DNA denaturation and $45 \mathrm{~s}$ at $58^{\circ} \mathrm{C}$ for primer and probe hybridization and DNA elongation

186 steps. The multiplex assay was carried out in a total volume of $20 \mu 1$, comprising $5 \mu 1$ of the

187 gDNA, $10 \mu 1$ of 2X QuantiFast Multiplex PCR master mix (Qiagen, CA), and between 75 and

$188200 \mathrm{nM}$ of each primer and TaqMan probe (Table 2). qPCR assay efficiencies were calculated

189 using standard curves based on 10-fold serial dilutions of gDNA from M. bovis ATCC 25523 for

190 the rpoB and 16S rRNA assays and A. laidlawii ATCC 23206 for the ITS assay.

191

192 Quantitative ranges of the qPCR assays

193

Serial dilutions were prepared of gDNA from M. bovis ATCC 25523, M. californicum

194 ATCC 33461, M. bovigenitalium ATCC 19852, and A. laidlawii ATCC 23206. The serial

195 dilutions spanned a $10^{6}$ - fold range, encompassing between approximately 5 fg to $5 \mathrm{ng}$ gDNA.

196 The QuantiFast Multiplex PCR Master mix was used in combination with the primer and probe

197 concentrations described in Table 2 with an annealing temperature of $58^{\circ} \mathrm{C}$. The assays were

198 tested in singleplex and multiplex in triplicate and in two separate runs and for each gDNA

199 primer/probe combination. To estimate genome equivalents, it was assumed that the average

200 base pair weighs $650 \mathrm{~g} / \mathrm{mol}$ and the average genome sizes were $1 \mathrm{Mbp}$ for M. bovis (Wise et al.,

201 2011), $0.79 \mathrm{Mbp}$ for M. californicum (Calcutt et al., 2014), $0.86 \mathrm{Mbp}$ for M. bovigenitalium

202 (Hata et al., 2017), and 1.5 Mbp for A. laidlawii (Lazarev et al., 2011). For verifying assay

203 specificity, a total of 1 to $25 \mathrm{ng}$ gDNA from diverse bacterial strains (Table 1) was tested for

204 detection using the Mycoplasma-M. bovis-A. laidlawii multiplex assay. 
To examine the quantitative range of the multiplex assay in milk, raw bovine milk

206 samples were first confirmed to be free of Mycoplasma spp. by plating on modified mycoplasma 207 agar and incubation at $37^{\circ} \mathrm{C}$ in $4 \% \mathrm{CO}_{2}$ for 7 days. Next, $1 \times 10^{6}$ to $1 \times 10^{8}$ colony-forming units 208 (CFU)/mL of M. bovis ATCC 25523, M. californicum ATCC 33461, and A. laidlawii ATCC 20923206 were inoculated into separate aliquots of that milk. The cell suspensions were immediately 210 used for serial dilutions in the same raw milk so that the final cell numbers spanned a $10^{4}$-fold 211 (M. californicum) to $10^{6}$ - fold (M. bovis and A. laidlawii) range. gDNA was then extracted and 212 tested with the Mycoplasma-M. bovis-A. laidlawii multiplex assay using conditions described in 213 Table 2 before setting qPCR multiplex assay detection criteria (Table 3).

215 Multi-species detection Mixtures of M. bovis ATCC 25523 and A. laidlawii ATCC 23206 gDNA were tested 217 with the multiplex assay to assess for the capacity for simultaneous, multi-species detection. 218 gDNA was mixed instead of intact cells because growth rate variations between the strains 219 limited our capacity to obtain sufficient cell numbers within the same period of time. To prepare 220 the gDNA mixtures, gDNA was extracted from a single strain immediately after inoculation into 221 separate aliquots of raw milk at either low $\left(10^{2}\right.$ to $\left.10^{3} \mathrm{CFU} / \mathrm{mL}\right)$, medium $\left(10^{3}\right.$ to $\left.10^{4} \mathrm{CFU} / \mathrm{mL}\right)$, 222 or high $\left(10^{6}\right.$ to $\left.10^{7} \mathrm{CFU} / \mathrm{mL}\right)$ cell numbers. Next, gDNAs from those strains were mixed in equal 223 volumes (1:1 ratios) and tested with the multiplex assay using the assay conditions described in 224 Table 2. A total of nine combinations of gDNAs, representing low, medium, and high levels of 225 M. bovis and A. laidlawii cells were measured (Table 4). 226

\section{7 qPCR performance on field milk samples}



of 52 frozen $\left(-20^{\circ} \mathrm{C}\right)$ bulk tank and individual cow milk samples were first confirmed to be 230 either Mycoplasma spp. culture positive or negative. This was determined by plating the milk

231 samples directly on modified mycoplasma agar and after enrichment in mycoplasma specific

232 broth for $24 \mathrm{~h}$ in $4 \% \mathrm{CO}_{2}$ at $37{ }^{\circ} \mathrm{C}$. Colonies were evaluated by the same person at 4 and 7 days and verified as M. bovis, M. bovigenitalium, or M. alkalescens using staining with fluorescent antibodies according to previously described methods (Baas and Jasper, 1972). The 52 milk samples were anonymized for testing by the qPCR multiplex assay and $5 \mu$ of total DNA extracted from the milk was tested using assay parameters described in Table 2. Diagnostic sensitivity (Se) and diagnostic specificity (Sp) of the multiplex qPCR assay was calculated as reference, the number of true positive (TP), true negative (TN), false positive (FP), and false negative (FP) samples were combined into following formulas: Se $(\%)=\mathrm{TP} /(\mathrm{TP}+\mathrm{FN})$ and $\mathrm{Sp}$ $(\%)=\mathrm{TN} /(\mathrm{TN}+\mathrm{FP})$. Kappa, an estimate of agreement beyond chance between laboratory

242 culture and qPCR was estimated and interpreted as $<40 \%$, poor; 41 to $75 \%$, fair to good; $>75 \%$, 243 excellent (Fleiss et al., 2003).

\section{RESULTS}


251 Tang et al., 2000). After testing between 75 and $200 \mathrm{nM}$ of each primer and TaqMan probe, the

252 Taqman qPCR assay parameters (QuantiFast Multiplex PCR master mix; annealing temperature

253 of $58^{\circ} \mathrm{C}$ ) and assay primer and probe concentrations were set as described in Table 2 . The qPCR

254 efficiencies for each of the individual qPCR assays on intended target gDNA ranged from 90 to

255 102.4\% when tested separately (in singleplex) (Table 2 and Supplementary Figure 2) and

256 combined into one Mycoplasma-M. bovis-A. laidlawii multiplex assay (Table 2 and Figure 1).

257 For the 16S rRNA gene assay in multiplex, the qPCR amplification efficiency was high for $M$.

258 bovis (Table 2) (96.8\%) and comparable to efficiencies found for M. californicum ATCC 33461

259 (102.4\%) and M. bovigenitalium ATCC19852 (97.9\%). The correlation coefficient of the straight

260 line, $R^{2}$ was higher than 0.98 for all assays over a $10^{6}$-fold range in singleplex (Supplementary

261 Figure 2) and multiplex (Figure 1). The lower limit of detection (LLD) for each assay was

262 similar between the singleplex (Supplementary Figure 2) and multiplex (Figure 1) formats $(C t$

263 values from 30 to 35). Both formats were able to detect low numbers of DNA copies per PCR

264 (50 fg DNA, approximately equal to 30 to 58 genome equivalents for the respective species

265 being targeted by the assay).

266

267 Specificity of the multiplex qPCR assays

268 We next examined the qPCR assays for cross-reactivity between the other species targets 269 contained in the Mycoplasma-M. bovis-A. laidlawii multiplex test. No amplification $(C t>37)$

270 was found for the A. laidlawii 16-23S ITS assay when tested on either M. bovis ATCC25523, $M$.

271 californicum ATCC33461, or M. bovigenitalium ATCC19852 gDNA template (data not shown).

272 For the $M$. bovis rpoB assay, some amplification $\left(C_{t}\right.$ values 31 to 37$)$ was observed for $M$.

273 californicum ATCC 33461 and M. bovigenitalium ATCC 19852 gDNA. However, that Ct range 
274 of detection was approximately $17 \mathrm{Ct}$ values higher than observed for equivalent quantities of the

275 M. bovis target ( $0.5 \mathrm{ng}$ ), comparable to a $10^{5}$ to $10^{6}$-fold difference in detection sensitivity. For

276 the Mycoplasma $16 \mathrm{~S}$ rRNA assay, some amplification $\left(C_{t}\right.$ values 31 to 35$)$ was observed for $A$.

277 laidlawii ATCC 23206 gDNA at the highest quantity of gDNA tested ( $0.5 \mathrm{ng})$. However, just as

278 found for the $r p o B$ assay, those $C t$ values were also much higher ( $C t$ difference of 17) than when

279 A. laidlawii was used as the target, comparable to a $10^{5}$ to $10^{6}$ - fold difference in detection.

280 No amplification $(C t>37)$ was observed with the Mycoplasma-M. bovis-A. laidlawii

281 multiplex assay for any non-Mycoplasma strains from 33 different bacterial species, including

282 representatives of the Staphylococcus, Bacillus, Aerococcus, Enterococcus, Enterobacter,

283 Escherichia, Klebsiella, Proteus, Prototheca, Pseudomonas, Serratia, and Streptococcus genera

284 (Table 1). As expected, gDNA from Mycoplasma californicum, Mycoplasma bovigenitalium, 285 Mycoplasma canadense, Mycoplasma arginini, and Mycoplasma alkalescens isolates (Table 1)

286 resulted in amplification with the $16 \mathrm{~S}$ rRNA assay $(C t$ values $<28)$ but not with the $r p o B$ and

287 ITS assays ( $C t$ values $>37)$. Moreover, gDNA from $A$. laidlawii field isolates only resulted in

288 amplification with the ITS assay, while three other field isolates of M. bovis from milk were

289 accurately detected by the rpoB and 16S rRNA assays ( $C t$ values ranged from between 21 to 24).

290

291 Limit of Detection (LOD) of multiplex qPCR assay in milk

292

Next, the qPCR multiplex assay range of detection was tested for Mycoplasma and $A$.

293 laidlawii in milk. A DNA amplification efficiency of 95 to $106 \%\left(R^{2}>0.98\right)$ was found for all

294 three gene targets spanning a $10^{4}$ to $10^{6}$-fold range when the multiplex assay was applied on

295 gDNA extracted from serial dilutions of M. californicum ATCC33461, M. bovis ATCC25523, or

296 A. laidlawii ATCC23206 contained in milk (Figure 2). However, it was noted that milk alone 
297 (no-template control or mycoplasma culture negative) sometimes resulted in some DNA 298 amplification ( $C t$ cycles 33 to 37 ). Therefore, $C t$ values above 33 were reported as negative for 299 the multiplex qPCR assay. To avoid false positives, a LOD cut-off $C t$ value was set at $<32$ for 300 Mycoplasma, $<33$ for M. bovis, and $<32$ for $A$. laidlawii (Table 3). Those cut-off $C t$ values for 301 each target assay were selected based on a minimum 3-Ct difference between the lowest 302 quantities of the target organism in milk and the negative control $C t$. Based on cell numbers 303 resulting in that $C t$, the LOD was within the range of 120 to $250 \mathrm{CFU} / \mathrm{mL}$.

305

306

307 308 309 310

311

312

313

314 315 316 317 318 319

\section{Multi-species detection with the multiplex qPCR assay}

Application of the multiplex qPCR assay on gDNA from M. bovis ATCC 25523 and $A$. laidlawii ATCC 23206 mixed in different proportions showed that multiplex assay could simultaneously detect $M$. bovis and A. laidlawii present in the same sample (Table 4). The 16S rRNA and $r р о B$ targeted assays were positive when gDNA from milk containing either moderate ( $10^{3}$ to $\left.10^{4} \mathrm{CFU} / \mathrm{mL}\right)$ to high $\left(10^{6}\right.$ to $\left.10^{7} \mathrm{CFU} / \mathrm{mL}\right)$ numbers of $M$. bovis was applied, irrespective of A. laidlawii gDNA abundance. Similarly, the A. laidlawii ITS qPCR assay results were positive when gDNA from milk containing moderate or high numbers of $A$. laidlawii was used, even in the presence of high quantities of $M$. bovis gDNA. Neither organism was detectable according to qPCR when the gDNA was extracted from milk with low cell numbers $\left(10^{2}\right.$ to $10^{3}$ CFU/mL) (Table 4).

\section{qPCR performance on field milk samples}

To determine the extent to which the Mycoplasma-M. bovis-A. laidlawii multiplex qPCR assay can reliably detect and differentiate between M. bovis from non-bovis Mycoplasma spp. 
320 and A laidlawii, a total 52 milk samples collected from bulk tanks and individual cows on CA

321 dairy farms were analyzed with the assay and the results were compared to laboratory culture-

322 based detection methods (Table 5). No sample was shown to contain A. laidlawii and therefore

323 the presence of that organism in field milk samples was not evaluated. Using the Mycoplasma

324 spp. qPCR criteria we set for the multiplex assay (Table 3), no false-positive results, Sp 100\%

$325(95 \%$ CI 86.8, 100; $\mathrm{n}=26)$ were obtained for the milk samples found to lack Mycoplasma spp.

326 according to laboratory culture-based methods (Table 5). Similarly, using the M. bovis criteria,

327 no false positive results, Sp 100\% (95\% CI 90.5, 100; $\mathrm{n}=37)$ were obtained for the milk samples

328 found to lack M. bovis (Table 5). Notably, the assay parameters were discriminative because

329 even though the rроB Ct value was relatively low (approximately 32 ) for sample ID\# 482582, a

330 sample found to contain M. alkalescens according to laboratory culture-based methods, there was

331 an approximate five-Ct difference between the $r p o B$ and $16 \mathrm{~S}$ rRNA assays. That difference was

332 beyond the allowable limit for M. bovis by the multiplex assay (Table 3).

333 A total of 24 out of 26 milk samples that tested positive for Mycoplasma spp. according

334 to CFU isolation in laboratory culture medium were also positive according to $\mathrm{qPCR}, \mathrm{Se} 92.3 \%$

335 (95\% CI: 74.9, 99.1; $\mathrm{n}=26)$. The remaining two samples (ID\# 41672 and ID\# 43960) were

336 negative by qPCR for all three gene targets but tested positive for M. alkalescens after

337 enrichment and plating for CFU identification. (Table 5).

338 The multiplex assay also accurately detected 14 out of 15 milk samples determined to

339 contain M. bovis according to culture-based methods, yielding a Se of 93.3\% (95\% CI: 68.1,

340 99.8; $\mathrm{n}=15$ ) for $M$. bovis. The remaining milk sample (ID\# 2927-3) tested positive for

341 Mycoplasma spp. but not M. bovis (Table 5). That sample resulted in only two presumptive $M$.

342 bovis colonies (approximately $100 \mathrm{CFU} / \mathrm{ml}$ ) (Table 5). Notably the average $C t$ for that sample 
343 (Ct of 33.76) was only slightly above the upper $C t$ value cut-off for $M$. bovis $(C t \leq 33)$ (Table 3)

344 and the $C t$ for Mycoplasma detection with the 16S rRNA gene was near to the limit of the

345 acceptable range ( $C t$ of 31.03 compared to $C t<32$ ).

346 Both assays, laboratory culture and qPCR, had excellent agreement beyond chance as

347 measured by Kappa. Specifically, the agreement between laboratory culture and qPCR in

348 detecting milk samples test positive for Mycoplasma spp. was 92.31\% (SE 13.83; P value <0.01)

349 and for M. bovis was 95.22\% (SE 13.85; P value <0.01).

350

351 DISCUSSION

352

The TaqMan multiplex qPCR assay developed here was shown to be a rapid and reliable

353 diagnostic tool for detection of Mycoplasma spp. and discrimination between Mycoplasma and

354 A. laidlawii in milk. The assay was accurate and showed a large dynamic range for quantification

355 (10 $10^{6}$ fold range) while maintaining a comparable sensitivity to that of the individual assays for

356 each target. Simultaneous detection was achieved for M. bovis and A. laidlawii and the

357 diagnostic sensitivity and field performance of the multiplex qPCR assay was confirmed. The

358 assay is a significant advancement for mastitis diagnostics because it emphasizes M. bovis

359 detection while also affording the possibility for detection of other Mycoplasma genera and

360 simultaneous detection and differentiation of non-pathogenic A. laidlawii contaminants.

361 The individual qPCR assays used here target genes that have also previously shown to be

362 useful for Mycoplasma and A. laidlawii detection by other methods. Conventional PCR assays

363 targeting Mycoplasma 16S rRNA genes were used for detection (Hirose et al., 2001) and both

364 detection and differentiation of different Mycoplasma spp., including M. bovigenitalium and $M$.

365 californicum (McAuliffe et al., 2005). For developing genus specific primers, target sequences 
366

367

368

369

370

371

372

373

374

375

376

377

378

379

380

381

382

383

384

385

386

387 388

used should have the greatest sequence divergence between genera but be conserved for species within the same genus. The $16 \mathrm{~S}$ rRNA gene is an ideal target in this regard since the presence of two gene copies also increases the detection limit for PCR. In comparisons between the $16 \mathrm{~S}$ rRNA genes of Mycoplasma and other related species including M. californicum, $M$.

bovigenitalium, M. alkalescens, $M$. arginini and $M$. canadense, we observed significant sequence similarity in the V7 variable region. This finding agreed with a previous study which concluded that mycoplasma genus-specific sequences occur between the 16S rRNA V6 and V7 regions, although some cross reactivity was found with Acholeplasma species (van Kuppeveld et al., 1992). The alignment of the V7 regions showed a 118-bp sequence which distinguished $A$. laidlawii from Mycoplasma spp., while being conserved among Mycoplasma species.

A variety of $M$. bovis genes including, uvrC, gltX, fus $A$ and oppD have been targets for species detection by PCR methods (Clothier et al., 2010; Rossetti et al., 2010; Sachse et al., 2010; Boonyayatra et al., 2012; Naikare et al., 2015; Gioia et al., 2016; Behera et al., 2018; Appelt et al., 2019). We selected rpoB, the gene encoding the highly conserved beta-subunit of the bacterial RNA polymerase, for assay development because there were more nucleotide variations in this gene between $M$. bovis and other Mycoplasma species. rpoB was also found to be a suitable target for phylogenetic analysis of Mycoplasma spp. including M. bovis (Kim et al., 2003). The use of the rpoB gene for M californicum detection in milk has already been explored in a probe-based, real-time PCR assay (Boonyayatra et al., 2012; Parker et al., 2017). Therefore, in this study, we used a 232-bp sequence in $r p o B$ gene for the design of primers and probe that could as well detect $M$. bovis in milk samples. Additionally, the rpoB gene assay reached a higher amplification efficiency compared to the qPCR assay we previously developed for $M$. bovis targeting gltX (Appelt et al., 2019). 
rRNA operons in A. laidlawii) was used for species-specific primers and probe development.

391 The ITS region was previously shown to have sufficient heterogeneity to differentiate between

392 Mycoplasma spp. and A. laidlawii (Tang et al., 2000; Gioia et al., 2016). This finding is

393 consistent with the lack of amplification observed for M. bovis or the other Mycoplasma tested

394 with that assay.

395

The individual qPCR assays performed well when combined in multiplex qPCR, with no

396

397

398

399

400

401

402

403

404

405

406

407

408

409

410

observed cross-reactivity between primer pairs and impacts on the dynamic range of target

detection. The multiplex assay was also capable of detecting gDNA from as few as 210 to 250

$\mathrm{CFU} / \mathrm{mL}$ in milk for each of the targets. The sensitivity of this qPCR method is comparable to other assays which reported a detection limit for $M$. bovis in a range of between 10 and 240

CFU/mL reported in milk (Clothier et al., 2010; Sachse et al., 2010; Boonyayatra et al., 2012).

Our assay was also more sensitive than the LOD reported for a multiplex qPCR assay targeting uvrC in M. bovis, rpoB in M. californicum, and the ITS region in M. bovigenitalium (Parker et al., 2017). In that study, the detection limit was $130 \mathrm{CFU} / \mathrm{mL}, 600 \mathrm{CFU} / \mathrm{mL}$, and $10^{5} \mathrm{CFU} / \mathrm{mL}$ for M. bovis, M californicum, and M. bovigenitalium, respectively. Sensitivity decreased by 100to 1000 -fold when all three species were present at the same time to simulate a multispecies infection (Parker et al., 2017). Our prior qPCR assay and methods targeting the M. bovis gltX was less sensitive to detect low quantities of $M$. bovis cells. The detection limit was between 10 to 100 gDNA copies per reaction, corresponding to $10^{4}$ to $10^{5}$ cells per mL (Appelt et al., 2019). However, it should be noted that a rapid DNA extraction method was used along with other Taq polymerase reagents which may have impacted estimates of $M$. bovis detection limits.

Peer) reviewing PDF | (2021:03:58967:1:0:NEW 20 Jun 2021) 
412 laidlawii in the same sample in $6 \%$ of the farms and mixed mycoplasma infections in $14 \%$ of the

413 farms (Gioia et al., 2016). Multispecies detection could be useful when testing for mastitis

414 because the occurrence of mixed mycoplasma spp. infection has been reported previously, with

415 M. bovis being isolated in approximately $90 \%$ of those cases and other species of mycoplasma

416 are isolated as secondary pathogens or contaminants (Kirk et al., 1997; Szacawa et al., 2015).

417 The multiplex qPCR assay reliably detected M. bovis and A. laidlawii gDNA when mixed

418 together. This indicated that M. bovis would be detectable, even with high levels of $A$. laidlawii

419 contaminants. Future studies will investigate the sensitivity of the multiplex qPCR assay for

420 mixed Mycoplasma species present in milk samples.

421 The multiplex assay showed a high level of Sp and Se when tested on milk samples

422 collected from different dairy farms in CA. Multiplex qPCR yielded a Se of 92.3\% for 16S

423 rRNA and $93.3 \%$ for $r p o B$ and a Sp of $100 \%$ for each of the targets compared with milk samples

424 confirmed by traditional laboratory bacterial culture methods. These results are comparable to

425 those obtained by others examining for M. bovis in milk (Clothier et al., 2010; Parker et al.,

426 2017; Appelt et al., 2019). Even though the sample size for the field validation test was small, no

427 false positive results were obtained. Instead, such samples were correctly identified as negatives

428 by qPCR as they did not meet the assay criteria for species/genera identification even when

429 culture results were positive. We suggest that qPCR negative results can be associated with the

430 presence of PCR inhibitors or low Mycoplasma cell numbers which might have led to a general

431 decrease in PCR sensitivity. In the former case the utilization of a DNA internal control in the

432 same tube as the target can eliminate false-negative PCR results caused by PCR inhibiting

433 substances, whereas in the latter case the multiplex assay cannot be used for direct detection in 
434 milk samples containing bacterial numbers below the detection limit as it requires these samples

435 to be enriched before detection. Estimation of the diagnostic sensitivity and specificity estimates

436 for A. laidlawii was not possible given that none of the study samples tested positive for $A$.

437 laidlawii by laboratory culture. In addition, estimates of diagnostic accuracy for Mycoplasma

438 spp. and Mycoplasma bovis reported here should be interpreted with caution given the small

439 sample size used in their diagnostic test evaluation.

440

\section{CONCLUSIONS}

442 Because the multiplex assay results in amplifying all three target DNA sequences within

443 the same tube, the costs, labor, and time required for sample preparation are reduced. This assay

444 therefore provides an opportunity for more rapid diagnosis of contagious Mycoplasma pathogens

445 and the reduction of risk for false positive results caused by A. laidlawii. In particular, the assay

446 can be used as a first pass identification method for making preliminary decisions on

447 mycoplasma diagnosis, thereby minimizing the risk of pathogen spread within dairy herds. 
450

451

452

453

454

455

456

457

458

459

460

461

462

463

464

465

466

467

468

469

470

471

472

473

474

475

476

477

478

479

480

481

\section{REFERENCES}

Appelt S, Aly SS, Tonooka K, Glenn K, Xue Z, Lehenbauer TW, and Marco ML. 2019. Development and comparison of loop-mediated isothermal amplification and quantitative polymerase chain reaction assays for the detection of Mycoplasma bovis in milk. Journal of Dairy Science 102:1985-1996 DOI 10.3168/jds.2018-15306.

Baas EJ, and Jasper DE. 1972. Agar block technique for identification of mycoplasmas by use of fluorescent antibody. Applied Microbiology 23:1097-1100.

Ball H.J. 1999. Impact of mycoplasma mastitis in cattle. In: Stipkovits L, Rosengarten R, Frey J, eds. Mycoplasmas of Ruminants: Pathogenicity, Diagnostics, Epidemiology and Molecular Genetics. Brussels: European Commission, 32-35.

Behera S, Rana R, Gupta PK, Kumar D, Sonal, Rekha V, Arun TR, and Jena D. 2018. Development of real-time PCR assay for the detection of Mycoplasma bovis. Tropical Animal Health Production 50:875-882 DOI 10.1007/s11250-018-1510-1.

Boonyayatra S, Fox LK, Besser TE, Sawant A, Gay JM, and Raviv Z. 2012. A PCR assay and PCR-restriction fragment length polymorphism combination identifying the 3 primary Mycoplasma species causing mastitis. Journal of Dairy Science 95:196-205 DOI 10.3168/jds.2011-4531.

Brenner J, Lysnyansky I, Elad D, Blum S, Bernstein M, Friedgut O, and Rotenberg D. 2009. Granulo-pustular vulvovaginitis ("Jackal bite") an emerging disease: Mycoplasma bovigenitalium and M. canadense infection of dairy cattle in Israel. Israel Journal of Veterniary Medicine 64:103-107

Calcutt MJ, Foecking MF, and Fox LK. 2014. Complete genome sequence of the bovine mastitis pathogen Mycoplasma californicum strain ST-6T (ATCC 33461T). Genome Announcements 2:e00648-14 DOI 10.1128/genomeA.00648-14.

Cha E, Bar D, Hertl JA, Tauer LW, Bennett G, Gonzalez RN, Schukken YH, Welcome FL, and Grohn YT. 2011. The cost and management of different types of clinical mastitis in dairy cows estimated by dynamic programming. Journal of Dairy Science 94:4476-4487 DOI 10.3168/jds.2010-4123.

Chapela M-J, Garrido-Maestu A, and Cabado AG. 2015. Detection of foodborne pathogens by qPCR: A practical approach for food industry applications. Cogent Food and Agriculture 1:1013771 DOI 10.1080/23311932.2015.1013771. 
482

483

484

485

486

487

488

489

490

491

492

493

494

495

496

497

498

499

500

501

502

503

504

505

506

507

508

509

510

Chavez Gonzalez YR, Ros Bascunana C, Bolske G, Mattsson JG, Fernandez Molina C, and Johansson KE. 1995. In vitro amplification of the 16S rRNA genes from Mycoplasma bovis and Mycoplasma agalactiae by PCR. Veterinary Microbiology 47:183-190 DOI 10.1016/0378-1135(95)00058-I.

Clothier KA, Jordan DM, Thompson CJ, Kinyon JM, Frana TS, and Strait EL. 2010. Mycoplasma bovis real-time polymerase chain reaction assay validation and diagnostic performance. Journal of Veterinary Diagnostic Investigation 22:956-960 DOI $10.1177 / 104063871002200618$.

Cornelissen JB, de Bree FM, van der Wal FJ, Kooi EA, Koene MG, Bossers A, Smid B, Antonis AF, and Wisselink HJ. 2017. Mycoplasma detection by triplex real-time PCR in bronchoalveolar lavage fluid from bovine respiratory disease complex cases. $B M C$ Veterinary Research 13:97 DOI 10.1186/s12917-017-1023-6.

Drancourt, M., C. Bollet, A. Carlioz, R. Martelin, J. P. Gayral, and D. Raoult. 2000. 16S ribosomal DNA sequence analysis of a large collection of environmental and clinical unidentifiable bacterial isolates. Journal of Clinical Microbiology 38:3623-3630 DOI 10.1128/JCM.38.10.3623-3630.2000.

Drancourt M, Raoult D. 2002. rрoB gene sequence-based identification of Staphylococcus species. Journal of Clinical Microbiology 40:1333-1338 DOI 10.1128/jcm.40.4.13331338.2002 .

Edward DG, and Freundt EA. 1956. The classification and nomenclature of organisms of the pleuropneumonia group. Journal of General Microbiology 14:197-207 DOI 10.1099/00221287-14-1-197.

Fleiss, JL, Levin B, and Paik MC. 2003. The measurement of interrater agreement. In: Statistical Methods for Rates and Proportions, 3rd ed. Wiley NY, USA: 604

Fox LK, Kirk JH, Britten A. 2005. Mycoplasma mastitis: a review of transmission and control. Journal of Veterinary Medicine. B Infectious Diseases and Veterinary Public Health Series 52:153-160 DOI 10.1111/j.1439-0450.2005.00845.x.

Fox LK. 2012. Mycoplasma mastitis: causes, transmission, and control. Veterinary Clinics of North America: Food Animal Practice 28:225-237 DOI 10.1016/j.cvfa.2012.03.007.

Peer) reviewing PDF | (2021:03:58967:1:0:NEW 20 Jun 2021) 
511 Gioia G, Werner B, Nydam DV, and Moroni P. 2016. Validation of a mycoplasma molecular 512 diagnostic test and distribution of mycoplasma species in bovine milk among New York 513 dairy farms. Journal of Dairy Science 99:4668-4677 DOI 10.3168/jds.2015-10724.

514 Hata E, Nagai K, and Murakami K. 2017. Complete genome sequence of Mycoplasma

515

516

517

518

519

520

521

522

523

524

525

526

527

528

529

530

531

532

533

534

535

536

537

538

539

540 bovigenitalium strain HAZ 596 from a bovine vagina in Japan. Genome Announcements 5:e01554-16 DOI 10.1128/genomeA.01554-16.

Hirose K, Kawasaki Y, Kotani K, Tanaka A, Abiko K, Ogawa H. 2001. Detection of mycoplasma in mastitic milk by PCR analysis and culture method. Journal of Veterinary Medical Science 63:691-693 DOI 10.1292/jvms.63.691.

Infante-Martinez F, Aguado J, and Eduard-Jasper D. 1999. Mastitis outbreak due to Mycoplasma californicum and Mycoplasma canadense in a commercial dairy herd in the state of Jalisco, Mexico. Revista Latinoamericana de Microbiologia 41:117-120.

Jasper DE. 1982. The role of Mycoplasma in bovine mastitis. Journal of the American Veterinary Medical Association 181:158-162.

Kim, K. S., Ko, K. S., Chang, M. W., Hahn, T. W., Hong, S. K. \& Kook, Y. H. (2003). Use of rpoB sequences for phylogenetic study of Mycoplasma species. FEMS Microbiology Letters 226:299-305 DOI 10.1016/S0378-1097(03)00618-9.

Kirk JH, Glenn K, Ruiz L, and Smith E. 1997. Epidemiologic analysis of Mycoplasma spp. isolated from bulk-tank milk samples obtained from dairy herds that were members of a milk cooperative. Journal of the American Veterinary Medical Association 211:10361038.

Lazarev VN, Levitskii SA, Basovskii YI, Chukin MM, Akopian TA, Vereshchagin VV, Kostrjukova ES, Kovaleva GY, Kazanov MD, Malko DB, Vitreschak AG, Sernova NV, Gelfand MS, Demina IA, Serebryakova MV, Galyamina MA, Vtyurin NN, Rogov SI, Alexeev DG, Ladygina VG, and Govorun VM. 2011. Complete genome and proteome of Acholeplasma laidlawii. Journal of Bacteriology 193:4943-4953 DOI 10.1128/jb.05059-11.

Maunsell FP, Woolums AR, Francoz D, Rosenbusch RF, Step DL, Wilson DJ, Janzen ED. 2011. Mycoplasma bovis infections in cattle. Journal of Veterinary Internal Medicine 25:772-783 DOI: 10.1111/j.1939-1676.2011.0750.x. 
541 McAuliffe, L., R. J. Ellis, J. R. Lawes, R. D. Ayling, and R. A. Nicholas. 2005. 16S rDNA

542

543

544

545

546

547

548

549

550

551

552

553

554

555

556

557

558

559

560

561

562

563

564

565

566

567

568

569

570

PCR and denaturing gradient gel electrophoresis; a single generic test for detecting and differentiating Mycoplasma species. Journal of Medical Microbiology 54:731-739 DOI 10.1099/jmm.0.46058-0.

Naikare H, Bruno D, Mahapatra D, Reinisch A, Raleigh R, and Sprowls R. 2015.

Development and evaluation of a novel taqman real-time PCR assay for rapid detection of Mycoplasma bovis: Comparison of assay performance with a conventional PCR assay and another taqman real-time PCR assay. Veterinary Sciences 2:32-42 DOI

\subsection{0/vetsci2010032.}

Nicholas RA, Fox LK, and Lysnyansky I. 2016. Mycoplasma mastitis in cattle: To cull or not to cull. The Veterinary Journal 216:142-147 DOI 10.1016/j.tvj1.2016.08.001.

Parker AM, House JK, Hazelton MS, Bosward KL, and Sheehy PA. 2017. Comparison of culture and a multiplex probe PCR for identifying Mycoplasma species in bovine milk, semen and swab samples. PLoS One 12:e0173422 DOI 10.1371/journal.pone.0173422.

Pfutzner H, and Sachse K. 1996. Mycoplasma bovis as an agent of mastitis, pneumonia, arthritis and genital disorders in cattle. Revue Scientifique et Technique 15:1477-1494. DOI: $10.20506 /$ rst.15.4.987.

Razin S. 1996. Mycoplasmas. In: Baron S, editor. Medical Microbiology. 4th ed. Galveston (TX): University of Texas Medical Branch at Galveston. Available at https://www.ncbi.nlm.nih.gov/books/NBK7637/

Rossetti BC, Frey J, and Pilo P. 2010. Direct detection of Mycoplasma bovis in milk and tissue samples by real-time PCR. Molecular and Cellular Probes 24:321-323. DOI 10.1016/j.mcp.2010.05.001.

Sachse K, Salam HS, Diller R, Schubert E, Hoffmann B, and Hotzel H. 2010. Use of a novel real-time PCR technique to monitor and quantitate Mycoplasma bovis infection in cattle herds with mastitis and respiratory disease. Veterinary Journal 186:299-303. DOI 10.1016/j.tvj1.2009.10.008.

Schrader C, Schielke A, Ellerbroek L, Johne R. 2012. PCR inhibitors - occurrence, properties and removal. Journal of Applied Microbiology 113:1014-1026. DOI 10.1111/j.13652672.2012.05384.x.

Peer] reviewing PDF | (2021:03:58967:1:0:NEW 20 Jun 2021) 
571 Szacawa E, Niemczuk K, Dudek K, Bednarek D, Rosales R, and Ayling R. 2015.

572 Mycoplasma bovis infections and co-infections with other Mycoplasma spp. with

573 different clinical manifestations in affected cattle herds in eastern region of Poland.

574 Bulletin of the Veterinary Institute in Pulawy 59:331 DOI 10.1515/bvip-2015-0049.

575 Tang J, Hu M, Lee S, and Roblin R. 2000. A polymerase chain reaction based method for

576 detecting Mycoplasma/Acholeplasma contaminants in cell culture. Journal of

577 Microbiological Methods 39:121-126 DOI 10.1016/S0167-7012(99)00107-4.

578 Thompson JD, Higgins DG, and Gibson TJ. 1994. Clustal W: improving the sensitivity of

579 progressive multiple sequence alignment through sequence weighting, position-specific

580 gap penalties and weight matrix choice. Nucleic Acids Research 22:4673-4680 DOI

$581 \quad 10.1093 /$ nar/22.22.4673.

582 Thurmond MC, Holmberg CA, and Luiz DM. 1989. Evaluation of a digitonin disk assay to

583 discriminate between acholeplasma and mycoplasma isolates from bovine milk. The

$584 \quad$ Cornell Veterinarian 79:71-81.

585 van Kuppeveld FJ, van der Logt JT, Angulo AF, van Zoest MJ, Quint WG, Niesters HG,

586 Galama JM, and Melchers WJ. 1992. Genus- and species-specific identification of

587 mycoplasmas by $16 \mathrm{~S}$ rRNA amplification. Applied Environmental Microbiology

$588 \quad 58: 2606-2615$ DOI 10.1128/AEM.58.8.2606-2615.1992.

589 Wise KS, Calcutt MJ, Foecking MF, Röske K, Madupu R, and Methé BA. 2011. Complete 590 genome sequence of Mycoplasma bovis type strain PG45 (ATCC 25523). Infection and 591 Immunity 79:982-983 DOI 10.1128/iai.00726-10.

592

593

594

595

596

597

598

599 
601 Table 1. Bacterial strains used in this study.

602

\begin{tabular}{|c|c|}
\hline Organism & Strain/Source ${ }^{a}$ \\
\hline Mycoplasma bovis & ATCC 25523 and field isolates $(n=3)$ \\
\hline Mycoplasma californicum & ATCC 33461 and field isolates $(n=3)$ \\
\hline Mycoplasma bovigenitalium & ATCC 19852 and field isolates $(n=3)$ \\
\hline Mycoplasma canadense & ATCC 29410 and field isolates $(n=3)$ \\
\hline Mycoplasma arginini & ATCC 23838 and field isolates $(n=3)$ \\
\hline Mycoplasma alkalescens & ATCC 29103 and field isolates $(n=3)$ \\
\hline Acholeplasma laidlawii & ATCC 23206 and field isolate $(n=3)$ \\
\hline Aerococcus viridans & ATCC 700406 \\
\hline Bacillus cereus & MQ 17 \\
\hline Enterobacter cloacae subsp cloacae & ATCC 13847 \\
\hline Enterobacter sp. & MQ 14M0100-3 \\
\hline Enterococccus faecalis & ATCC 29212 \\
\hline Enterococcus durans & MQ 15M0470-1 \\
\hline Enterococcus faecium & ATCC 35667 \\
\hline Enterococcus gallinarium & ATCC 700425 \\
\hline Escherichia coli & ATCC 25922 \\
\hline Klebsiella pneumoniae & MQ 14 \\
\hline Proteus hauseri & ATCC 13315 \\
\hline Prototheca species & MQ 16M1258-4 \\
\hline Pseudomonas aeruginosa & ATCC 10145 \\
\hline Serratia marcescens & MQ 15M0394-3 \\
\hline Staphylococcus aureus & MQ 16M1264-9; ATCC 25923 \\
\hline Staphylococcus capitis subsp capitis & ATCC 35661 \\
\hline Staphylococcus chromogenes & DFSL 8435 \\
\hline Staphylococcus cohnii & ATCC 35662 \\
\hline Staphylococcus epidermidis & DFSL 1780 \\
\hline Staphylococcus haemolyticus & DFSL 8043 \\
\hline Staphylococcus pasteuri & DFSL 8109 \\
\hline Staphylococcus warneri & MQ 15M0945 \\
\hline Staphylococcus xylosus & ATCC 35663 \\
\hline Streptococcus agalactiae & ATCC 27956 \\
\hline Streptococcus dysgalactiae subsp dysgalactiae & ATCC 27957 \\
\hline Streptococcus dysgalactiae subsp equisimilis & ATCC 35666 \\
\hline Streptococcus equi subsp zooepidemicus & ATCC 700400 \\
\hline Streptococcus equinus & MQ 15M0757-12 \\
\hline Streptococcus infantarius subsp coli & ATCC 27960 \\
\hline Streptococcus mutans & MQ 15M1463-3 \\
\hline Streptococcus uberis & MQ 16M1263-101 \\
\hline Streptococcus uberis & ATCC 27958 \\
\hline Streptococcus uberis & ATCC 700407 \\
\hline
\end{tabular}

603

$604{ }^{\mathrm{a}} \mathrm{ATCC}=$ American Type Culture Collection (Manassas, VA); MQ = Milk Quality Laboratory (VMTRC,

605 UC Davis, Tulare, CA); DFSL = Dairy Food Safety Laboratory (VMTRC, UC Davis, Tulare, CA). 
Table 2. Sequences of primers, probes, PCR product sizes and amplification efficiency of the qPCR assays a

\begin{tabular}{|c|c|c|c|c|c|c|c|}
\hline \multirow[t]{2}{*}{ Organism } & \multirow[t]{2}{*}{ Target } & \multirow{2}{*}{$\begin{array}{l}\text { Primer and } \\
\text { Probe }^{b}\end{array}$} & \multirow[t]{2}{*}{ Primer and Probe Sequence (5' to $3^{\prime}$ ) } & \multirow[t]{2}{*}{$\mathbf{n M}$} & \multirow{2}{*}{$\begin{array}{l}\text { Product } \\
\text { (bp) }\end{array}$} & \multicolumn{2}{|c|}{ qPCR efficiency $(\%)^{c}$} \\
\hline & & & & & & Singleplex & Multiplex \\
\hline $\begin{array}{l}\text { Mycoplasma } \\
\text { spp }^{\mathrm{d}}\end{array}$ & 16S rRNA & $\begin{array}{l}\text { Myco_F } \\
\text { Myco_R } \\
\text { Myco_Probe }\end{array}$ & $\begin{array}{l}\text { CGAGCGCAACCCTTATCCTT } \\
\text { CCCCACTCGTAAGAGGCATGA } \\
\text { VIC-TCGTCCCCACCTTCCTCCCG-QSY }\end{array}$ & $\begin{array}{l}100 \\
100 \\
75\end{array}$ & 118 & $88.8-100.9$ & $96.8-102.4$ \\
\hline M. bovis & гров & $\begin{array}{l}\text { M.bovis_F } \\
\text { M.bovis_R } \\
\text { M.bovis_Probe }\end{array}$ & $\begin{array}{l}\text { TTTCAGCCGCTAACTTCAGAGC } \\
\text { GCAAGTTCCCCATCCTTGAAG } \\
\text { ABY-TCGCCTTTAGCAACTTCTTGACCAA- } \\
\text { QSY }\end{array}$ & $\begin{array}{l}200 \\
200 \\
200\end{array}$ & 232 & 87.1 & 95.6 \\
\hline A. laidlawii & ITS & $\begin{array}{l}\text { Achol_F } \\
\text { Achol_R } \\
\text { Achol_Probe }\end{array}$ & $\begin{array}{l}\text { AAGTGGGCAATACCCAACGC } \\
\text { ACGTTCCCGTAGGGATACCTTG } \\
\text { 6-FAM-ACGGCTCCCTCCCTTTCGGG-QSY }\end{array}$ & $\begin{array}{l}15015 \\
075\end{array}$ & 108 & 91.9 & 91.2 \\
\hline
\end{tabular}

607

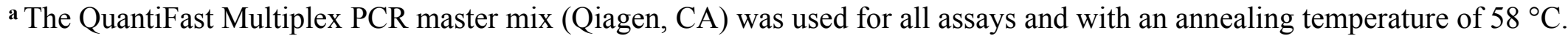

${ }^{\mathbf{b}} \mathrm{F}$ and $\mathrm{R}$ indicate forward and reverse primers, respectively. . TaqMan probes were designed with 6-FAM (6-carboxyfluorescein) VIC (2'-

611 ester) as the quencher dye on the $3^{\prime}$ end.

c Amplification efficiencies were determined using gDNA from M. bovis ATCC25523, M. californicum ATCC 33461, and M. bovigenitalium ATCC19852 (16S rRNA), M. bovis ATCC25523 (rpoB), and A. laidlawii ATCC 23206 (ITS). 
620 Table 3. Criteria for detection of Mycoplasma spp., M. bovis, and A. laidlawii in milk with

621 the TaqMan multiplex qPCR assay.

\begin{tabular}{|c|c|c|c|c|}
\hline \multirow{2}{*}{$\begin{array}{l}622 \\
623 \\
624\end{array}$} & & \multicolumn{3}{|c|}{ Gene target (Cut-off $C t$ value) } \\
\hline & Organism b $^{\text {b }}$ & $\begin{array}{c}\text { 16S rRNA } \\
\left(C_{t} \leq 32\right)\end{array}$ & $\begin{array}{c}r p o B \\
\left(C_{t} \leq 33\right)\end{array}$ & $\begin{array}{c}\text { ITS } \\
\left(C_{t} \leq 32\right)\end{array}$ \\
\hline 625 & Mycoplasma spp. & + & - & - \\
\hline & M. bovis ${ }^{\mathrm{c}}$ & + & + & - \\
\hline & A. laidlawii & - & - & + \\
\hline
\end{tabular}

627

$628{ }^{\text {a }} \mathrm{Ct}=$ Threshold Cycle value; positive $(+)$ and negative (-) symbols indicate a positive and 629 negative result for that group of bacteria by the multiplex qPCR assay.

$630{ }^{\mathbf{b}}$ M. californicum ATCC33461 M, bovis ATCC25523, and A. laidlawii ATCC23206 were used 631 for determining LOD levels of Mycoplasma, M. bovis, and A. laidlawii, respectively.

$632 \mathrm{c} M$. bovis gDNA was expected to be detected by both the $16 \mathrm{~S}$ rRNA and $r p o B$ assays, therefore a 633 positive $M$. bovis sample is expected to have $<3 C t$ value difference for those targets. 634 
635 Table 4. Detection of $M$. bovis and A. laidlawii mixtures in milk with the multiplex qPCR

636 assay ${ }^{a}$.

637

638

639

640

641

642

643

644

\begin{tabular}{|c|c|c|c|}
\hline & & Target & $C t(\operatorname{avg} \pm \text { stdev })^{b}$ \\
\hline \multirow{9}{*}{ M. bovis (low) } & A. laidlawii (low) & 16S rRNA & $33.47 \pm 0.24$ \\
\hline & A. laidlawii (intermediate) & & $33.32 \pm 0.12$ \\
\hline & A. laidlawii (high) & & $33.41 \pm 0.41$ \\
\hline & A. laidlawii (low) & гров & $33.80 \pm 0.52$ \\
\hline & A. laidlawii (intermediate) & & $33.47 \pm 0.21$ \\
\hline & A. laidlawii (high) & & $33.49 \pm 0.66$ \\
\hline & A. laidlawii (low) & ITS & $32.91 \pm 0.38$ \\
\hline & A. laidlawii (intermediate) & & $25.65 \pm 0.07$ \\
\hline & A. laidlawii (high) & & $15.79 \pm 0.11$ \\
\hline \multirow{9}{*}{$\begin{array}{r}\text { M. bovis } \\
\text { (intermediate) }\end{array}$} & A. laidlawii (low) & 16S rRNA & $27.44 \pm 0.11$ \\
\hline & A. laidlawii (intermediate) & & $27.42 \pm 0.12$ \\
\hline & A. laidlawii (high) & & $27.22 \pm 0.16$ \\
\hline & A. laidlawii (low) & гров & $27.05 \pm 0.23$ \\
\hline & A. laidlawii (intermediate) & & $26.97 \pm 0.10$ \\
\hline & A. laidlawii (high) & & $26.83 \pm 0.31$ \\
\hline & A. laidlawii (low) & ITS & $32.87 \pm 0.51$ \\
\hline & A. laidlawii (intermediate) & & $25.71 \pm 0.07$ \\
\hline & A. laidlawii (high) & & $15.77 \pm 0.07$ \\
\hline \multirow{9}{*}{ M. bovis (high) } & A. laidlawii (low) & 16S rRNA & $16.68 \pm 0.15$ \\
\hline & A. laidlawii (intermediate) & & $16.63 \pm 0.18$ \\
\hline & A. laidlawii (high) & & $16.90 \pm 0.05$ \\
\hline & A. laidlawii (low) & гров & $16.38 \pm 0.19$ \\
\hline & A. laidlawii (intermediate) & & $16.42 \pm 0.22$ \\
\hline & A. laidlawii (high) & & $16.58 \pm 0.14$ \\
\hline & A. laidlawii (low) & ITS & $36.70 \pm 0.71$ \\
\hline & A. laidlawii (intermediate) & & $26.02 \pm 0.15$ \\
\hline & A. laidlawii (high) & & $15.69 \pm 0.05$ \\
\hline
\end{tabular}

${ }^{\mathrm{a}} \mathrm{gDNA}$ was extracted from milk inoculated with M. bovis ATCC 25523 and A. laidlawii ATCC 23206 at either low $\left(10^{2}\right.$ to $\left.10^{3} \mathrm{CFU} / \mathrm{mL}\right)$, medium $\left(10^{3}\right.$ to $\left.10^{4} \mathrm{CFU} / \mathrm{mL}\right)$, or high $\left(10^{6}\right.$ to $10^{7}$

$\mathrm{CFU} / \mathrm{mL})$.

${ }^{\mathrm{b}}$ Shading indicates average $C t$ values within range for detection $(\mathrm{n}=3)$ using qPCR criteria for multiplex assay given in Table 3. 
645able 5. Laboratory culture and multiplex qPCR results for field milk samples. 646

\begin{tabular}{|c|c|c|c|c|c|c|c|c|}
\hline \multirow[b]{3}{*}{ ID\# } & \multirow[b]{3}{*}{$\begin{array}{c}\text { Sample } \\
\text { Type }^{a}\end{array}$} & \multicolumn{3}{|c|}{ Laboratory Culture $^{\text {b }}$} & \multicolumn{4}{|c|}{ Multiplex qPCR Result $(C t)^{c}$} \\
\hline & & \multirow[b]{2}{*}{ DP } & \multirow[b]{2}{*}{ MB } & \multirow[b]{2}{*}{ Organism } & \multicolumn{3}{|c|}{ Gene Target } & \multirow[b]{2}{*}{ Organism } \\
\hline & & & & & $\begin{array}{c}16 S \\
\text { rRNA }\end{array}$ & rров & ITS & \\
\hline 4750 & $\mathrm{C}$ & $\geq 400$ & + & M. bovis & $+(15.10)$ & $+(17.18)$ & - & M. bovis \\
\hline $1331-2$ & $\mathrm{~T}$ & 4 & + & M. bovis & $+(29.79)$ & $+(31.43)$ & - & M. bovis \\
\hline $1985-1$ & $\mathrm{~T}$ & 85 & + & M. bovis & $+(24.60)$ & $+(25.90)$ & - & M. bovis \\
\hline $2927-3$ & $\mathrm{~T}$ & 2 & - & M. bovis & $+(31.03)$ & $-(33.76)$ & - & $\begin{array}{c}\text { Mycoplasma } \\
\text { sp. }\end{array}$ \\
\hline $3145-1$ & $\mathrm{~T}$ & + & + & M. bovis & $+(27.70)$ & $+(32.35)$ & - & M. bovis \\
\hline $3606-1$ & $\mathrm{~T}$ & + & + & M. bovis & $+(26.97)$ & $+(28.34)$ & - & M. bovis \\
\hline $3642-1$ & $\mathrm{~T}$ & $\geq 100$ & + & M. bovis & $+(25.16)$ & $+(27.80)$ & - & M. bovis \\
\hline $3915-1$ & $\mathrm{~T}$ & + & + & M. bovis & $+(26.17)$ & $+(27.32)$ & - & M. bovis \\
\hline $\begin{array}{c}43722- \\
1\end{array}$ & $\mathrm{~T}$ & $\geq 200$ & + & M. bovis & $+(23.19)$ & $+(24.91)$ & - & M. bovis \\
\hline $\begin{array}{c}43897- \\
1\end{array}$ & $\mathrm{~T}$ & 4 & + & M. bovis & $+(28.81)$ & $+(31.46)$ & $-(34.4)$ & M. bovis \\
\hline $4395-1$ & $\mathrm{~T}$ & $\geq 600$ & + & M. bovis & $+(26.27)$ & $+(27.55)$ & - & M. bovis \\
\hline $\begin{array}{c}43967- \\
2 \\
\end{array}$ & $\mathrm{~T}$ & 1 & + & M. bovis & $+(29.42)$ & $+(31.45)$ & $-(34.52)$ & M. bovis \\
\hline $4435-1$ & $\mathrm{~T}$ & 9 & + & M. bovis & $+(29.44)$ & $+(30.62)$ & $-(36.74)$ & M. bovis \\
\hline $4437-1$ & $\mathrm{~T}$ & $\geq 200$ & + & M. bovis & $+(23.94)$ & $+(24.95)$ & $-(35.99)$ & M. bovis \\
\hline $4784-1$ & $\mathrm{~T}$ & 9 & + & M. bovis & $+(27.63)$ & $+(29.77)$ & $-(34.96)$ & M. bovis \\
\hline 8229 & $\mathrm{C}$ & - & + & $\begin{array}{c}M . \\
\text { bovigenitalium }\end{array}$ & $+(17.84)$ & $-(34.89)$ & $-(37.21)$ & $\begin{array}{c}\text { Mycoplasma } \\
\text { sp. }\end{array}$ \\
\hline 180 & C & - & + & M. alkalescens & $+(31.16)$ & - & - & $\begin{array}{c}\text { Mycoplasma } \\
\text { sp. }\end{array}$ \\
\hline 6141 & $\mathrm{C}$ & - & + & M. alkalescens & $+(29.31)$ & $-(38.47)$ & - & $\begin{array}{c}\text { Mycoplasma } \\
\text { sp. }\end{array}$ \\
\hline 33257 & $\mathrm{C}$ & - & + & M. alkalescens & $+(26.78)$ & $-(35.35)$ & - & $\begin{array}{c}\text { Mycoplasma } \\
\text { sp. }\end{array}$ \\
\hline 39494 & C & - & + & M. alkalescens & $+(25.85)$ & $-(38.41)$ & - & $\begin{array}{c}\text { Mycoplasma } \\
\text { sp. }\end{array}$ \\
\hline 41672 & $\mathrm{C}$ & - & + & M. alkalescens & - & - & - & - \\
\hline 42275 & $\mathrm{C}$ & 6 & + & M. alkalescens & $+(25.25)$ & $-(36.52)$ & $-(34.61)$ & $\begin{array}{c}\text { Mycoplasma } \\
\text { sp. }\end{array}$ \\
\hline 43960 & $\mathrm{C}$ & - & + & M. alkalescens & $-(34.67)$ & - & $-(32.43)$ & - \\
\hline 482582 & C & 1 & + & M. alkalescens & $+(26.46)$ & $-(31.54)$ & - & $\begin{array}{c}\text { Mycoplasma } \\
\text { sp. }\end{array}$ \\
\hline 749 & C & 85 & + & M. alkalescens & $+(19.99)$ & $-(35.69)$ & - & $\begin{array}{c}\text { Mycoplasma } \\
\text { sp. }\end{array}$ \\
\hline 750 & $\mathrm{C}$ & - & + & M. alkalescens & $+(26.76)$ & $-(34.34)$ & - & $\begin{array}{c}\text { Mycoplasma } \\
\text { sp. }\end{array}$ \\
\hline 829 & $\mathrm{C}$ & - & - & - & $-(32.42)$ & $-(34.28)$ & $-(34.89)$ & - \\
\hline 818 & $\mathrm{C}$ & - & - & - & $-(33.07)$ & $-(35.25)$ & $-(35.56)$ & - \\
\hline 802 & $\mathrm{C}$ & - & - & - & $-(33.18)$ & $-(33.88)$ & - & - \\
\hline 828 & C & - & - & - & $-(33.43)$ & $-(34.23)$ & $-(34.07)$ & - \\
\hline 809 & C & - & - & - & $-(33.57)$ & $-(34.22)$ & - & - \\
\hline 819 & $\mathrm{C}$ & - & - & - & $-(34.19)$ & $-(34.09)$ & $-(34.71)$ & - \\
\hline 815 & $\mathrm{C}$ & - & - & - & $-(34.54)$ & - & - & - \\
\hline 810 & C & - & - & - & $-(34.57)$ & $-(34.58)$ & - & - \\
\hline 826 & $\mathrm{C}$ & - & - & - & $-(34.83)$ & $-(34.35)$ & $-(36.11)$ & - \\
\hline 823 & $\mathrm{C}$ & - & - & - & $-(34.96)$ & - & $-(33.46)$ & - \\
\hline 804 & C & - & - & - & $-(35.26)$ & - & $-(36.09)$ & - \\
\hline 822 & C & - & - & - & $-(35.40)$ & - & - & - \\
\hline 814 & $\mathrm{C}$ & - & - & - & $-(35.85)$ & - & - & - \\
\hline
\end{tabular}




\begin{tabular}{|l|l|l|l|l|l|l|l|l|}
\hline 824 & C & - & - & - & $-(36.02)$ & $-(38.96)$ & $-(35.90)$ & - \\
\hline 801 & C & - & - & - & $-(36.03)$ & - & - & - \\
\hline 808 & C & - & - & - & $-(36.06)$ & $-(34.92)$ & $-(35.19)$ & - \\
\hline 803 & C & - & - & - & $-(36.17)$ & $-(39.70)$ & - & - \\
\hline 820 & C & - & - & - & $-(36.94)$ & - & $-(34.57)$ & - \\
\hline 812 & C & - & - & - & $-(37.08)$ & $-(34.66)$ & - & - \\
\hline 817 & C & - & - & - & $-(37.37)$ & - & - & - \\
\hline 806 & C & - & - & - & $-(37.65)$ & $-(35.19)$ & $-(34.94)$ & - \\
\hline 811 & C & - & - & - & $-(37.90)$ & - & - & - \\
\hline 813 & C & - & - & - & $-(38.00)$ & $-(35.11)$ & $-(34.94)$ & - \\
\hline 821 & C & - & - & - & $-(38.25)$ & - & - & - \\
\hline 807 & C & - & - & - & - & - & $-(34.88)$ & - \\
\hline 816 & C & - & - & - & - & - & $-(34.84)$ & - \\
\hline
\end{tabular}

64Cow (C) or Bulk Tank (T) milk sample

64B $\mathrm{P}=$ Direct plating. Based on results from direct plating of milk samples on modified mycoplasma 6Agar using cotton swabs; MB = Mycoplasma Broth. Based on culture results of $24 \mathrm{~h}$ enriched broth 650mples; Plates with bacterial growth are indicated by a plus (+) and no growth by a minus (-); 6\$4coplasma spp. were identified by fluorescently labeled, species-specific antibody staining method. 65The positive qPCR results are indicated by a plus (+) and negative results by a minus (-); Mycoplasma 65Psp. were identified by $C t$ cut-off criteria (Table 3 ).

654 


\section{Figure Legends}

657

658 Figure 1. Standard curves for the 16S rRNA, rpoB and ITS TaqMan qPCR assays

659 performed in multiplex. The standard curves were constructed with 10-fold serial dilutions of

660 M. bovis ATCC 25523 (16S rRNA and rpoB assays), M. bovigenitalium ATCC 19852 (16S

661 rRNA assay), M. californicum ATCC 33461 (16S rRNA assay), and A. laidlawii ATCC 23206

662 (ITS assay) gDNA, ranging from between approximately 5 fg to 5 ng gDNA. Results shown are

663 from a single run with each dilution tested in triplicate. The $\mathrm{R}^{2}$ value was 0.99 for the standard

664 curve of each target (16S rRNA, rpoB and ITS). Error bars indicate standard deviation ( \pm ) based 665 on the results for three replicates.

666

667 Figure 2. Limit of detection of multiplex assay for M. bovis, M. californicum, and $A$.

668 laidlawii in milk. Serial dilutions of M. bovis ATCC 25523 (starting cell number of $2.5 \times 10^{8}$

$669 \mathrm{CFU} / \mathrm{mL}$ ), M. californicum ATCC 33461 (starting cell number of $2.3 \mathrm{X} 10^{6} \mathrm{CFU} / \mathrm{mL}$ ), and $A$.

670 laidlawii ATCC $23206\left(1.22 \times 10^{8} \mathrm{CFU} / \mathrm{mL}\right)$ were performed in Mycoplasma - negative raw

671 milk prior to gDNA extraction and target detection with the multiplex qPCR assay. Results

672 shown are from a single run with each dilution tested in duplicate. The $\mathrm{R}^{2}$ value was 0.99 for the

673 standard curve of each target (16S rRNA, rроB and ITS). Error bars indicate standard deviation

$674( \pm)$ based on the results for all replicates. 


\section{Figure 1}

Standard curves for the $16 \mathrm{~S}$ rRNA, rpoB and ITS TaqMan qPCR assays performed in multiplex.

The standard curves were constructed with 10-fold serial dilutions of M. bovis ATCC 25523 (16S rRNA and rpoB assays), M. bovigenitalium ATCC 19852 (16S rRNA assay), M.

californicum ATCC 33461 (16S rRNA assay), and A. laidlawii ATCC 23206 (ITS assay) gDNA, ranging from between approximately $5 \mathrm{fg}$ to $5 \mathrm{ng}$ gDNA. Results shown are from a single run with each dilution tested in triplicate. The $\mathrm{R}^{2}$ value was 0.99 for the standard curve of each target (16S rRNA, rpoB and ITS). Error bars indicate standard deviation ( \pm ) based on the results for three replicates. 

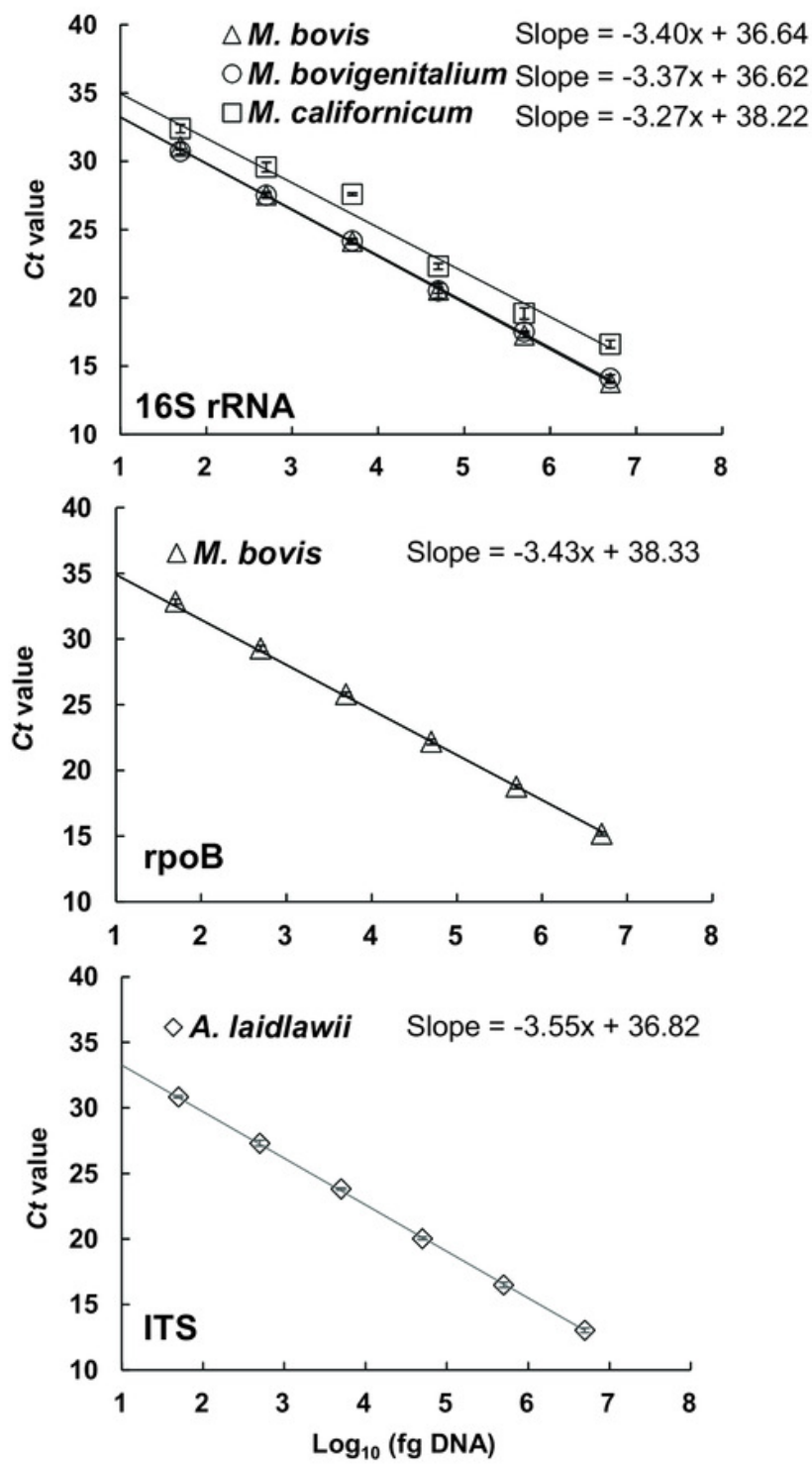


\section{Figure 2}

Limit of detection of multiplex assay for M. bovis, M. californicum, and A. laidlawii in milk.

Serial dilutions of $M$. bovis ATCC 25523 (starting cell number of $2.5 \times 10^{8} \mathrm{CFU} / \mathrm{mL}$ ), $M$. californicum ATCC 33461 (starting cell number of $2.3 \times 10^{6} \mathrm{CFU} / \mathrm{mL}$ ), and A. laidlawii ATCC $23206\left(1.22 \times 10^{8} \mathrm{CFU} / \mathrm{mL}\right)$ were performed in Mycoplasma - negative raw milk prior to gDNA extraction and target detection with the multiplex qPCR assay. Results shown are from a single run with each dilution tested in duplicate. The $\mathrm{R}^{2}$ value was 0.99 for the standard curve of each target (16S rRNA, rpoB and ITS). Error bars indicate standard deviation ( \pm ) based on the results for all replicates. 

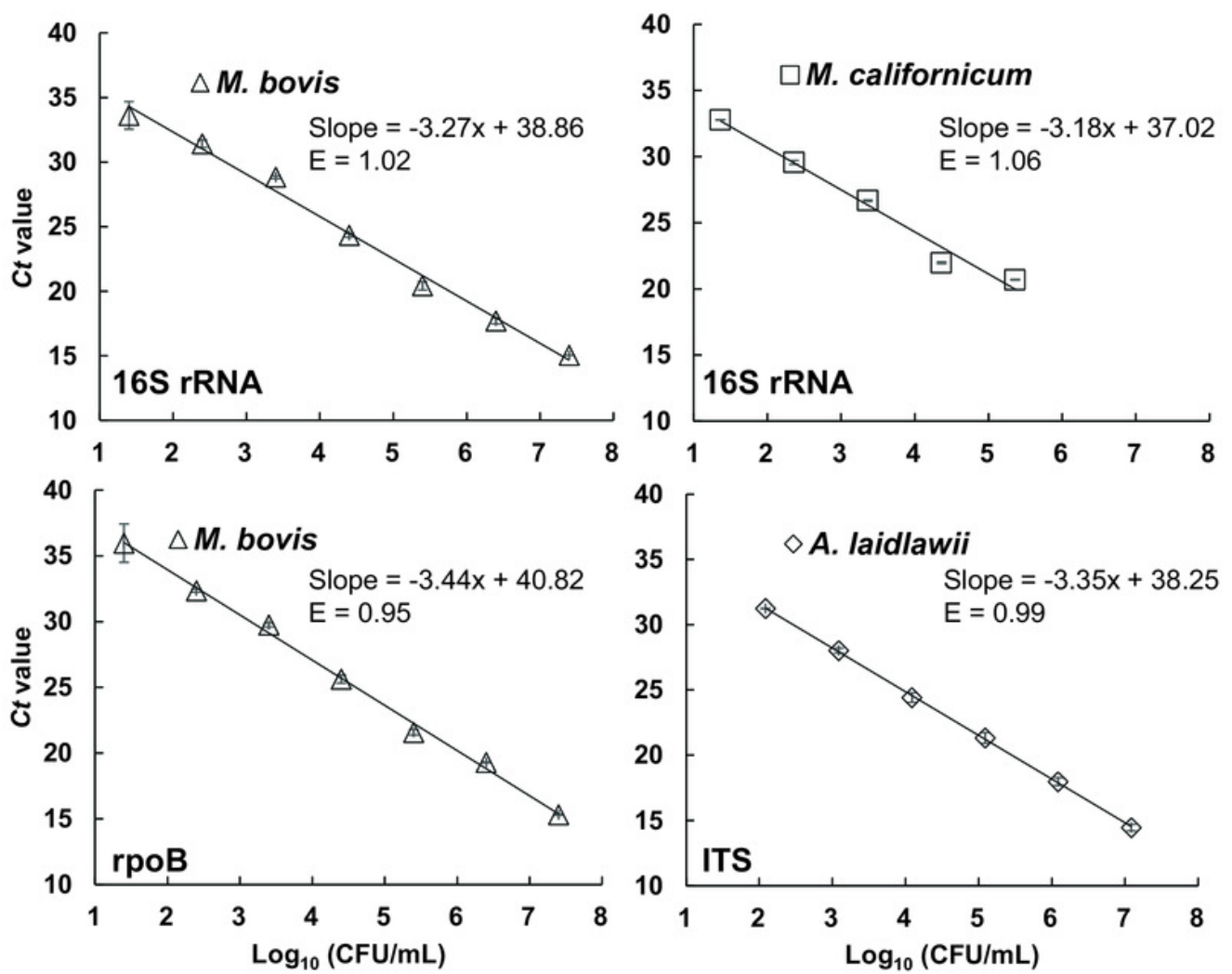